\title{
Comparison of Repetitive Sprint Performance for the U16 and U18 Category Soccer Players
}

\author{
Bade Yamak*, Osman İmamoğlu \\ Yasar Doğu Faculty of Sports Science, Ondokuz Mayıs University, Turkey
}

Copyright $\mathrm{C} 2019$ by authors, all rights reserved. Authors agree that this article remains permanently open access under the terms of the Creative Commons Attribution License 4.0 International License

\begin{abstract}
The aim of this study is to examine 20-meter repetitive sprint performance every 20 seconds in the U 16 and U18 category soccer players. It is also to create normative data for 20 -meter repetitive sprint performance for football players. In our study, 22 players at Soccer's U16 category and 23 players at Soccer's at U18 category performed a test of 10 repetitive 20-meter sprints at every 20 seconds. On the statistical analysis, t-tests were used for the comparison of two groups. In order to determine the effect of average speed and the sprint quantity for the groups, two ways analysis of variance were done. In U16 and U18 category soccer players, it's founded out that the difference of age and weight is meaningful $(p<0,001)$. However; the height difference wasn't meaningful ( $p>0,05)$. In this study, it is the running speed of 20 meters found to be $5.10 \mathrm{~m} / \mathrm{sec}$ for U16 and $5.42 \mathrm{~m} / \mathrm{sec}$ for U18 soccer players. At the U16 category, the least value at 1-2 speed run was $5.03 \mathrm{~m} / \mathrm{sec}$ and the highest value was $5.99 \mathrm{~m} / \mathrm{sec}$. At the U18 category, the least value was 4.91 $\mathrm{m} / \mathrm{sec}$ and the highest value was $7.37 \mathrm{~m} / \mathrm{sec}$. Also, it was found out that the decrease in average speed for 20 -meter repetition sprint was $\% 14.10$ for U16 and $\% 14.80$ for U18. In between U16 and U18 category soccer players, it is conducted that a difference on the average speed in the first two Sprints and the average speed in the last 2 Sprints $(p<0,001)$. In addition, the difference between the average speed of the first two sprints for each group and the average of the last two sprints were significant $(\mathrm{p}<0.001)$. Conclusion: Results of the age groups of U16 and U18 revealed no major differences for a 20 meter repeated sprint runs. U16 and U18 category soccer players performed a test of 10 pieces of 20-meter repetitive sprints at each 20 seconds for capacity development. The speed performance of U16 and U18 soccer players during the play should be recorded. The physical and the speed ability differences of soccer players should be evaluated at the beginning, during and at the end of the season. A coach can improve soccer players' anaerobic capacities with 20 -meter sprints. They can increase the resistance to density by doing 10 repetitions of 20 -meter sprint. Thus, the development of specific training programs aiming to
\end{abstract}

improve the sprint ability is recommended.

Keywords Soccer, Consecutive Sprints and Tiredness

\section{Introduction}

Football is one of the most popular team sports in the world, and millions of athletes practice it regularly as members of football clubs [1]. Among the physical parameters, the sprint ability, especially combined with short periods of recovery [2,3], is one of the most important elements, as it can discriminate football players into different levels $[4,5,6]$. One of the most important parts of today's soccer players' performance is that they are able to succeed at high speed short-distance runs of straight or different directions as much as possible from the beginning to the end of the game. The ability of gaining speed in short distance and time is important while possessing ball from maintaining the ball [7].

The football match analysis indicated that sprints over short distances are generally performed 17-81 times per match, and represent $8-12 \%$ of the distance covered by the players [1]. It is stated that during a soccer game, many of the sprints done with maximum power are generally straight and the sprint distance changes between 5-50 meters [8]. On the other hand, Withers et al. [9] states that during a game, maximal sprint distance changes between 20 and 30 meters. Ekblom [7] specifies that during a soccer game average sprint distance is 15 meters and maximum sprint distance is 40 meters. The same researches states that acceleration in sprints with high starts from a stable position up to 30 meters and also maximum running speed in sprints between 30 and 50 meters which start with gaining speed can be measured. Because of many speed runs during the game, today's tendency is to determine the protection level of average speed characteristics during consecutive sprints. Changing effects of growing conditions and their age factors of players are the subjects that haven't been not researched in Turkey. Based on the 
studies of Gall et al. [10], Mendez-Villanueva et al. [11] and Maly et al. [12], it can be suggested that the sprint ability improves from the ages of 12 to 18 years.

Sprinting has been suggested as the most frequent action performing before a goal [5]. Players in the German national football team were found to perform $\sim 17$ sprints per game [13]. The sprint ability in football is usually assessed using the $20 \mathrm{~m}$ sprint test, where the participants are asked to cover this distance as fastest as possible [1]. The $20 \mathrm{~m}$ sprint was selected as the test to be taken under consideration in the present study due to its relevance with the demands of a football match $[14,15]$.

The aim of this study is to examine 20 meter repetitive sprint performance every 20 seconds in the U 16 and U18 categories. It is also to create normative data for 20 -meter repetitive sprint performance for football players.

\section{Material and Method}

In this study, they are U16 category ( $\mathrm{n}=22$, between the ages of 14-16 years old) and U18 category male soccer players ( $\mathrm{n}=23,17-19$ years old physical education students who play soccer) were included. Soccer players in the U16 category have football history between 8-9 years and U18 category soccer players have 9-11 years as well. All datum was taken in 2015 in January. 4 measurements were done regarding to structural and speed characteristics at this study. All measurements belonging to all groups were taken at the same day in the afternoon just before training. Volunteered subjects rested one day before measurement without any loading. Measurements were taken 3 hours after lunch and after 20 minutes warming exercise. Stimulants as tea, coffee or cola were not allowed. In order, (1) height, (2) weight, (3) 20 meter times run by 10 repetitions were accomplished and recorded at sport saloon. Additionally their ages were recorded by checking ids. The subjects were weighted by 100 -gr sensitive scale wearing only shorts and T-shirt bare feet. The height measurements were done by metal stick combined with scale at right angle and at the right condition. The stick was checked at subject's head limit by $0.5 \mathrm{~cm}$ sensitivity.

The run time for 20 meters by maximum effort at every 20 seconds of soccer players of U 16 and U 18 category were measured 10 times. Prosport TMR ESC 2100 model telemetric chronometers obtained all speed measurements in the afternoon. Soccer players did 20-meter sprints on each 20 seconds with maximum effort repeated 10 times with high start position. This test was modified from Bangsbo [16] multi speed test. Subjects run at parquet floor. At the very beginning of start, Soccer player's front toe was located at the start point of run. Start and finish were recorded by 2 photocells located at 1 meter high from the floor at the beginning and at the end. The average running speed was calculated by dividing running distance and running time. The percentage of the difference between the averages of two runnings at the first and the averages of two running at the end was accepted as tiredness level. Additionally the best time and the average of 10 runnings were also recorded.

Soccer statistics at different runnings and the average speed datum were also calculated. T-test was used comparing physical characteristics of $U 16$ and $U 18$ category soccer players. To determine the effect of the age factor of players and 10 different speeds run, two ways analysis of variance (two way ANOVA) was used. Statistics were done at SPSS 21.00 package program. $p<0.05$ Meaning level was accepted at the determination of differences.

\section{Results}

Table 1. Comparison between the U 16 and U 18 Soccer Players' Physical Characteristics

\begin{tabular}{|c|c|c|c|c|c|}
\hline Variants & Group & $X \pm S d$ & Min-Max & $\begin{array}{c}\text { Average } \\
\text { Difference }\end{array}$ & $\mathbf{t}$ \\
\hline \multirow{2}{*}{$\begin{array}{c}\text { Age } \\
\text { (years) }\end{array}$} & U 16 & $15.30 \pm 0.13$ & $14.00-16.0$ & \multirow{2}{*}{-3.01} & \multirow{2}{*}{$-16.85^{* *}$} \\
\hline & U 18 & $18.31 \pm 0.16$ & $17.00-19.0$ & & \\
\hline \multirow{2}{*}{$\begin{array}{c}\text { Height } \\
\text { (cm) }\end{array}$} & U 16 & $172.34 \pm 1.14$ & $158.00-182.0$ & \multirow{2}{*}{-1.18} & \multirow{2}{*}{-1.25} \\
\hline & U 18 & $173.16 \pm 1.31$ & $164.0-185.0$ & & \\
\hline \multirow{2}{*}{$\begin{array}{c}\text { Weight } \\
\text { (kg) }\end{array}$} & U 16 & $61.13 \pm 1.02$ & $42.0-77.0$ & \multirow[t]{2}{*}{-15.50} & \multirow{2}{*}{$47.56^{* *}$} \\
\hline & U 18 & $72.63 \pm 1.79$ & $58.0-97.0$ & & \\
\hline
\end{tabular}

$\mathrm{X}=$ Mean $\quad$ Sd: standard deviation Min: Minimum max: Maximum

* In $\mathrm{p}<0.01$ level two between groups were found significantly different. 
Table 2. The average Speeds of the Consecutive 10 Sprints in the U 16 and U 18 category soccer players

\begin{tabular}{|c|c|c|c|c|}
\hline \multirow{2}{*}{$\begin{array}{c}\text { Sprint } \\
\text { Number }\end{array}$} & \multicolumn{4}{|c|}{ Average Running Speed (m/sec) } \\
\cline { 2 - 5 } & \multicolumn{3}{|c|}{ U 16 category soccer players } & \multicolumn{2}{c|}{ U 18 category soccer players } \\
\cline { 2 - 5 } & $\mathrm{X} \pm \mathrm{Sd}$. & Min-Max & $\mathrm{X} \pm$ Sd. & Min-Max \\
\hline 1 & $5.54 \pm 0.21$ & $4.09-5.93$ & $5.90 \pm 0.61$ & $4.98-8.37$ \\
\hline 2 & $5.52 \pm 0.25$ & $4.01-5.99$ & $5.87 \pm 0.64$ & $4.91-6.69$ \\
\hline 3 & $5.46 \pm 0.25$ & $4.77-5.78$ & $5.88 \pm 0.63$ & $4.92-6.67$ \\
\hline 4 & $5.32 \pm 0.31$ & $4.52-6.15$ & $5.49 \pm 0.77$ & $4.39-6.37$ \\
\hline 5 & $5.08 \pm 0.28$ & $4.46-5.57$ & $5.50 \pm 0.54$ & $4.84-6.37$ \\
\hline 6 & $4.96 \pm 0.36$ & $4.78-5.49$ & $5.27 \pm 0.53$ & $4.91-6.43$ \\
\hline 7 & $4.85 \pm 0.31$ & $4.18-5.41$ & $5.32 \pm 0.94$ & $4.99-6.81$ \\
\hline 8 & $4.73 \pm 0.29$ & $4.18-5.24$ & $4.93 \pm 0.53$ & $4.20-5.85$ \\
\hline 9 & $4.74 \pm 0.34$ & $4.15-5.63$ & $4.94 \pm 0.51$ & $4.18-6.06$ \\
\hline 10 & $4.76 \pm 0.49$ & $4.11-6.37$ & $5.07 \pm 0.53$ & $4.39-610$ \\
\hline Total & $5.10 \pm 0.45$ & $4.78-6.37$ & $5.42 \pm 0.74$ & \\
\hline
\end{tabular}

Table 3. Speeds in the United Sprints of the Soccer Players in the U 16 and U 18 Category soccer players

\begin{tabular}{|c|c|c|c|c|}
\hline \multirow{3}{*}{$\begin{array}{c}\text { Sprint } \\
\text { Number }\end{array}$} & \multicolumn{4}{|c|}{ Running Speed (m/sec) } \\
\hline & \multicolumn{2}{|c|}{ U 16 category soccer players } & \multicolumn{2}{|c|}{ U 18 category soccer players } \\
\hline & $\mathrm{X} \pm \mathrm{Sd}$ & Min-Max & $\mathrm{X} \pm \mathrm{Sd}$ & Min-Max \\
\hline $1-2$ & $5.53 \pm 0.23$ & 5.03-5.99 & $5.89 \pm 0.63$ & $4.91-7.37$ \\
\hline $3-4$ & $5.39 \pm 0.29$ & $4.52-6.15$ & $5.69 \pm 0.72$ & $4.39-6.67$ \\
\hline $5-6$ & $5.02 \pm 0.33$ & $4.78-5.57$ & $5.39 \pm 0.54$ & $4.84-6.43$ \\
\hline $7-8$ & $4.79 \pm 0.31$ & $4.18-5.41$ & $5.13 \pm 0.78$ & $4.99-8.81$ \\
\hline $9-10$ & $4.75 \pm 0.42$ & $4.13-6.32$ & $5.01 \pm 0.52$ & $4.20-6.04$ \\
\hline
\end{tabular}

Table 4. Two Way Variance Analysis of the Effects Sprint Number on Average Speed

\begin{tabular}{|c|c|c|c|c|c|}
\hline $\begin{array}{c}\text { Dependent } \\
\text { Variable }\end{array}$ & Factors & Total Square & df & Mean Square & F \\
\hline \multirow{2}{*}{$\begin{array}{c}\text { Average speed in the 5 sprints } \\
(\mathrm{m} / \mathrm{sec})\end{array}$} & United & 76.22 & 5 & 15.24 & $60.69^{* *}$ \\
\cline { 2 - 5 } & Group & 15.36 & 1 & 15.64 & $62.25^{* *}$ \\
\cline { 2 - 5 } & Sprint Number & 60.57 & 4 & 15.14 & $58.30^{* *}$ \\
\hline \multirow{2}{*}{$\begin{array}{c}\text { Average speed in the 10 Sprints } \\
(\mathrm{m} / \mathrm{sec})\end{array}$} & United & 81.31 & 10 & 8.13 & $31.84^{* *}$ \\
\cline { 2 - 5 } & Group & 15.36 & 1 & 15.64 & $64.16^{* *}$ \\
\cline { 2 - 5 } & Sprint Number & 65.67 & 9 & 7.30 & $28.47^{* *}$ \\
\hline
\end{tabular}

$\operatorname{In} * * \mathrm{p}<0.01$ level. Dependent variables and factors are significantly related.

Table 5. Comparison between the Decrease in the Average Speed of the First two and the last two Sprints of the Soccer's

\begin{tabular}{|c|c|c|c|c|c|}
\hline \multirow{2}{*}{ Variables } & \multicolumn{2}{|c|}{ U 16} & \multicolumn{2}{|c|}{ U 18} & \multirow{2}{*}{ t-test } \\
\hline & $\mathbf{X} \pm$ Sd. & Min-Max. & $\mathbf{X} \pm$ Sd. & Min-Max. & \\
\hline Average speed in the first two Sprints $(\mathrm{m} / \mathrm{sec})$ & $5.53 \pm 0.23$ & $5.01-5.99$ & $5.88 \pm 0.64$ & $4.91-8.37$ & $-5.21 * *$ \\
\hline Average speed in the Last 2 Sprints $(\mathrm{m} / \mathrm{sec})$ & $4.75 \pm 042$ & $4.11-6.37$ & $5.01 \pm 0.52$ & $4.18-6.06$ & $3.92 * *$ \\
\hline t-test & \multicolumn{2}{|c|}{$12.64 * *$} & \multicolumn{2}{|c|}{$8.78 * *$} & - \\
\hline Decrease in Average Speed $(\mathrm{m} / \mathrm{sec})$ & \multicolumn{2}{|c|}{0.78} & \multicolumn{2}{|c|}{0.87} & - \\
\hline Decrease in Average Speed\% & \multicolumn{2}{|c|}{14.10} & \multicolumn{2}{|c|}{14.80} & - \\
\hline
\end{tabular}

\footnotetext{
* $\quad \mathrm{p}<0.01$
} 


\section{Discussion}

The average age level of U 16 soccer players' was 15.30 years $(n=22)$, the average height level was $172.34 \mathrm{~cm}$, the average weight was $61.13 \mathrm{~kg}$ while the average age level of U 18 soccer players' was 18.31 years $(n=23)$, the average height level was $173.16 \mathrm{~cm}$ and the average weight was $72.63 \mathrm{~kg}$. In U 16 and $\mathrm{U} 18$ category soccer players, it was founded a meaningful difference of age and weight $(\mathrm{p}<0,001)$.In Addition it wasn't conducted a meaningful difference of height $(p>0,05)$.

In this study, it is the running speed of 20 meters was found to be $5.10 \mathrm{~m} / \mathrm{sec}$ for $\mathrm{U} 16$ and $5.42 \mathrm{~m} / \mathrm{sec}$ for $\mathrm{U} 18$ soccer players. At the $\mathrm{U} 16$ category, the least value at 1-2 speed run was $5.03 \mathrm{~m} / \mathrm{sec}$ and the highest value was 5.99 $\mathrm{m} / \mathrm{sec}$. At the U 18 category, the least value was $4.91 \mathrm{~m} / \mathrm{sec}$ and the highest value was $7.37 \mathrm{~m} / \mathrm{sec}$. At the $\mathrm{U} 16$ category, the least value at 9th and 10th speed run was $4.13 \mathrm{~m} / \mathrm{sec}$ and the highest value was $6.32 \mathrm{~m} / \mathrm{sec}$. At the U 18 category, the least value was $4.20 \mathrm{~m} / \mathrm{sec}$ and the highest value was $6.04 \mathrm{~m} / \mathrm{sec}$. When 5 sprints or consecutive sprints were evaluated or when each sprints were evaluated one by one, depending on the group and sprint numbers, the average acceleration speed changed meaningfully $(p<0.01)$. When the number of sprints increased, the average sprint time increased as well. The protection of average speed and velocity for U18 category soccer players is better than that of the U16 category soccer players. Nikolaidis et al. [1], study indicates that, for the $20 \mathrm{~m}$ sprint, the ability improved from U10 to U19 with the latter being the age of the peak performance.

In this study, it is at the $\mathrm{U} 16$ category, this decrease at 2 sprints of start and finish, is different from 0.01 meaningful level by t-value of 12.64. At the U 18 category, this decrease is $\% 14.80$ from $5.88 \mathrm{~m} / \mathrm{sec}$ to $5.01 \mathrm{~m} / \mathrm{sec}$. The difference at start and finish speed is different at 0.01 meaningful level by t-value 8.78 .

Both on U16 and U18 category soccer players, regarding to sprint time and parallels of the average speed and the sprint number, a change was observed. Related to number of sprints, it had a tendency to increase at sprint durations on both groups. The average sprint speeds at seniors on $1-4-7-10$ th sprints were $5.54,5.32,4,85$ and $4.76 \mathrm{~m} / \mathrm{sec}$. same values for U19 category were 9.90, 5.49, 5.32 and $5.07 \mathrm{~m} / \mathrm{sec}$. Similarly, at 2, 3-4, 5-6, 7-8 and 9-10th sprints average speed values for U 16 were 5.53, 5.39, 5.02, 4.79 and $4.75 \mathrm{~m} / \mathrm{sec}$ in order, and for U 18 category were 5.89 , $5.69,5.39,5.13$ and 5.01 in order. In total, U 16 performed less speed at average as $5.10 \mathrm{~m} / \mathrm{sec}$ compared to $5.44 \mathrm{~m} / \mathrm{sec}$ at U 18 category. U 16 showed a variance between $4.78-6.37 \mathrm{~m} / \mathrm{sec}$ at average speed and U 18 category showed a variance between $4.39-6.10 \mathrm{~m} / \mathrm{sec}$ at average speed. These results indicated that some soccer players at $U$ 16 category was faster than $U 18$ category soccer players.

When we took the average factor of each two sprints, we conducted that the acceleration speed changed meaningfully related to the group and the sprint numbers in total 5 sprints via evaluating the sprints one by one $(p<0.01)$. It also means that the number of sprints is related to the average sprint speed decrease. The average speed and the ability to protect the speed at $\mathrm{U} 18$ category is higher than the U 16 's category soccer players. It was found that the sprint time decreased across adolescence, with larger improvements being observed at the beginning than at the end of adolescence. For instance, Mendez-Villanueva et al. [11] observed a faster sprint time in the $0-10 \mathrm{~m}$ sprint for the $\sim 15$ years age group than the $\sim 13$ years $(-0.13 \mathrm{~s})$ age group, whereas the $\sim 17$ years age group was faster than the $\sim 15$ years group $(-0.07 \mathrm{~s})$. In this study, for determining the tiredness trend, concerning 1 st and 2nd, 3rd and 4th, 5th and 6th, 7th and 8th, 9th and 10th runs together would eliminate the little deviations, but evaluating one by one, differences can be seen more visible at 9th and 10th runs in details. In between U16 and U 18 category soccer players, it is found out a meaningful difference on the average speed in the first two sprints and the average speed in the last 2 sprints $(\mathrm{p}<0,001)$. In addition, the difference between the average speed of the first two sprints for each group and the average of the last two sprints were significant ( $p>0.001)$.

Bangsbo [16], recorded an average tiredness index as $0.64 \mathrm{sec}$ between 0.15-0.92 for 11 professional Danish soccer players, Aybek [17], recorded an average tiredness as 0.40 at amateur soccer players and 0.43 at students. Both research results' averages were less than values for males as 0.78 and values for females as $0.87 \mathrm{sec}$. At Albay [18] study, it was seen that for 10 consecutive 20 meter sprints decrease on speed was about \% 0.34 at professionals whereas the decrease at amateurs was \% 5.16. Imamoğlu et al. [19], found at the senior category, the average speed of $5.53 \mathrm{~m} / \mathrm{sec}$ at first 2 sprints was decreased by \% 14.29 level at the last 2 sprints to $4.74 \mathrm{~m} / \mathrm{sec}$. At the young category decrease was $\% 16.64$ from $6.01 \mathrm{~m} / \mathrm{sec}$ to $5.01 \mathrm{~m} / \mathrm{sec}$. The decreases at both groups were significant at 0.01 level. In this study, it was found the decrease in average speed for 20 meter sprint was \% 14.10 for U 16 and $\% 14.80$ for U 18 . The speed ability of the football players improved with age until 15 years old, when it reached its peak. This is due to the biological development of the young players, and the increase in the intensity of football training activities with age. On the other hand, the other age groups, U16 to U35 revealed no major differences in the speed over a $20 \mathrm{~m}$ sprint [1]. The differences on results might become due to the different grounds, different dates, different training loading methods or different growth component of the subjects. The difference between young and senior categories could be expressed by partial renewing of phosphogen structure at $20 \mathrm{sec}$ sprints at young subjects, less renewing at seniors subjects, and less muscle structure of female subjects comparing to male subjects and less pushing power and different anthropometrics structure [20]. Based on Nikolaidis et al. [1], findings, it is an evident that 
coaches should increase their focus on the development of the sprint ability in football players.

\section{Conclusions}

The running speed of 20 meters was found to be 5.10 $\mathrm{m} / \mathrm{sec}$ for U16 and $5.42 \mathrm{~m} / \mathrm{sec}$ for U18 soccer players. When the numbers of sprints increase, the average speed decreases. The results of age groups of U16 and U18 revealed no major differences for a $20 \mathrm{~m}$ repeated sprint runs. U16 and U18 category soccer players can perform a test of 10 pieces of 20 meter repetitive sprints at each 20 second for capacity development. The speed performance of $\mathrm{U} 16$ and $\mathrm{U} 18$ soccer players during a play should be recorded. In order to have preformation for talented children, the physical and speed ability evaluations should be applied to early-aged children in small groups and the children's acceleration, the maximum speed and the speed protection limits should be evaluated as well. At speed exercises, for every age and every sportsmen, the distance, the strength and the consecutive resting numbers should be recorded by many consecutive sprints. These evaluations should be done at different soccer players playing at different areas. The differences of the physical and the speed ability of soccer players should be evaluated at the beginning, during and at the end of the season. A coach can improve soccer players' anaerobic capacities with 20 meter sprints. They can increase the resistance to density by doing 10 repetitions of 20 meter sprint. Thus, the development of specific training programs aiming at improving the sprint ability is recommended.

\section{REFERENCES}

[1] Nikolaidis, P. T., B. Knechtle, F. Clemente and G. Torres-Luque (2016). "Reference values for the sprint performance in male football players aged from 9-35 years." Biomedical Human Kinetics 8(1): 103-112.

[2] Angius L., S. Olla, F. Piras, R. Mura, G. Ibba, F. Todde, M. Cominu, M. Pinna, F. Tocco, A. Concu, A. Crisafulli (2013). Indexes of physical capacity and repeated sprint ability of young soccer players. Sport Sci. Health, 9: 1-6. DOI:10.1007/s11332-013-0137-x.

[3] Perroni F., M. Corvino, L. Cignitti, C. Minganti (2013). RSA response to preseason training in semiprofessional soccer players. Sport Sci. Health, 9: 59-64.

DOI:10.1007/s11332-013-0146-9.

[4] Ferro A., J. Villacieros, P. Floría, J.L. Graupera (2014). Analysis of speed performance in soccer by a playing position and a sports level using a laser system. J. Hum. Kinet., 44: 143-153. DOI:10.2478/hukin-2014-0120.

[5] Haugen T.A., E. Tønnessen, J. Hisdal, S. Seiler (2014). The role and development of sprinting speed in soccer. Int. J. Sports Physiol. Perform, 9: 432-441. DOI:10.1123/IJSPP.2
013-0121.

[6] Koundourakis N.E., N.E. Androulakis, N. Malliaraki, C. Tsatsanis, M. Venihaki, A.N. Margioris (2014). Discrepancy between exercise performance, body composition, and sex steroid response after a six-week detraining period in professional soccer players. PLoS ONE, 9. DOI:10.1371/journal.pone.0087803.

[7] Ekblom, B. (1994) Handbook of Sports Medicine and Science, Football (Soccer). Blackwell Scientific publications, London, pp, 72-79.

[8] Wade, A. (1979) The F.A. Guide to Training and Coaching. Heineman: London.

[9] Whiters, R. G., D. Roberts, and G. J. Davies. (1977) The maximum Aerobic Power, Anaerobic Power and body Composition of South Australian Male Representatives in athletics, Basketball, Field Hockey, and soccer, Journal of Sports Medicine

[10] Le Gall F., J. Beillot, P. Rochcongar (2002) The improvement in maximal anaerobic power from soccer player during growth. Sci. Sports, 17: 177-188. DOI:10.1016/S0765-1597(02)00155-7.

[11] Mendez-Villanueva A., M. Buchheit, S. Kuitunen, A Douglas, E. Peltola, P. Bourdon (2011). Age-related differences in acceleration, maximum running speed, and repeated-sprint performance in young soccer players. J. Sports Sci., 29: 477-484.

DOI:10.1080/02640414.2010.536248.

[12] Malý T., F. Zahálka, P. Hráský, L. Mala, J. Ižovská, D. Bujnovský, M. Dragijský, J. Mihal (2015). Age-related differences in linear sprint and power characteristics in youth elite soccer players. J. Phys. Educ. Sport, 15: 857-863. DOI:10.7752/jpes.2015.04132.

[13] Schimpchen J., S. Skorski, S. Nopp, T. Meyer (2015). Are "classical" tests of repeated-sprint ability in football externally valid? A new approach to determine in-game sprinting behaviour in elite football players. J. Sports Sci., DOI:10.1080/02640414.2015.1112023.

[14] Bangsbo J., L. Nørregaard, F. Thorsø (1991) Activity profile of competition soccer. Can. J. Sport Sci., 16: 110-116.

[15] Reilly T., V. Thomas (1976). A motion analysis of work rate in different positional roles in professional football match play. J. Hum. Mov. Stud., 2: 87-97.

[16] Bangsbo,J. (1994) Fitness Training for Football: A Scientific Approach. HO+Storm. Bagsvaerd. Copenhagen. Denmark. In Bjorn Ekblom. Handbook of Sports Medicine vand Science, Football (Soccer). Blacwell Scientific Publications. London, pp., 108-109, 1994.

[17] Aybek, S. (2000) Amatör Futbolcuların Tekrarlı Sprint Testi İle Yorgunluk ve Toparlanma Düzeylerinin Belirlenmesi. Ondokuz Mayıs Üniversitesi, Sağlık Bilimleri Enstitüsü, Yayınlanmamıș Yüksek Lisans Tezi, Samsun.

[18] Albay, F. (1999) Futbolculara Uygulanan Tekrarlı Sürat Koşularının Yorgunluğa Etkisi. Ondokuz Mayıs Üniversitesi, Sağlık Bilimleri Enstitüsü, Yayınlanmamış Yüksek Lisans Tezi, Samsun.

[19] İmamoğlu, R., Can, İ., İmamoğlu, M., Albayrak, A.Y., İmamoğlu, O. "Comparison of Some Anthropometric, 
Physiological and Motor Performance Factors in Professional and Amateur Soccer Players', The 4th International Conference on Sports and Exercise Science: Well-Being Well Beyond Sport and Exercise, Bangkok / Thailand, 26-29 March 2013, (Poster Presentation). p.358

[20] Bompa T.O. (1986) Theory and Methodology of Training. Debuque, Iowa, pp.21, 213-248. 